UDK: 316.774-028.27:37-051/-052 Professional paper

\title{
DIGITAL ALPHABET - A CHALLENGE FOR THE MODERN STUDENT AND TEACHER
}

\section{Ruža Jeličić}

Technical school „Ivan Sarić” Subotica

Vojvodina, Serbia

ruzajelicic12@gmail.com 


\section{ABSTRACT}

The fruits of the digital age have become a key part of everyday life in hundreds of millions of households, offices and schools around the world. Our communication takes place far more via text messages and e-mail than face-to-face, and the first place we look for information is Google. The consequences of this technological ubiquity and electronic flood are significant shifts in the attitudes as well as in the behavior of students and teachers, and the goal of this paper is to examine these shifts. How is the digital age changing the opportunities, values and lives of students and teachers - what is happening now, what awaits us in the future? Can digital achievement really change the way students and teachers think or behave? Do both students and teachers learn a new alphabet - the digital alphabet?

Key words: digital era, future, student, teacher, youth. 


\section{INTRODUCTION}

Every journey into the future is a journey into the past. Each society is determined by its own tradition, but at the same time facing the future. The idea of a humane society is being conceived among people, while the gloomy technocratic and robotic George-Orwellian vision of society is imposed as the antipode to these ideas. Its psychosis is not without significance for explaining the rebellion of the young generation, which seeks humanity and direct democracy of people above all, not things and automatons.

The youth of our century have the opportunity to get acquainted with historical examples of the revolutionary transformation of the world. It is a witness to a reality in which there is constant encouragement to spend and change; in which everything is quickly consumed, quickly replaced: movies, devices, cars, love. The crisis of values did not appear only with the digital era. That crisis appeared many years ago, but it has only recently crossed the critical point, when there was an explosion. Sociologist Wright Mills (1966) has long warned that the moral turmoil of our time - in politics and economics, in family life, in educational institutions, and even in churches - should be attributed to this key fact: old values and rules of chastity no longer hold us back, new values and rules that would give moral meaning and confirmation to the routine of life that we must now follow.

Today's young generation is professionally and culturally at a higher level than previous generations. This is quite understandable if we take into account the possibilities of previous generations and the difficult historical conditions under which they developed, educated and improved. It is natural that the knowledge of this generation is at a far higher level. The scientific and technological revolution has provided excellent conditions for young people to express themselves far more than previous generations, but at the same time it has set them difficult tasks.

The modern generation openly expresses a completely new attitude towards traditional values. There is a kind of destruction of old values in almost all areas of socio - cultural life. In the controversy, young people oppose the established system of social values and announce new ones. On the other hand, there are objections that young people do not have a sense of dialectical acceptance of the hitherto positive in the developed system of cultural values and that they do not respect the older generations who built our society and culture with their creativity. It is natural for the new generation to create some new values that differ from the values of the previous generation. That generation is brought up and educated in the spirit of its time. 
Hard and tedious jobs, which once had to be done by slaves, are now largely automated. It remains for people to work to solve those problems that arise due to the fact that machines have shortcomings. Whether it is about the use of drones or digital networking of the world, we rely on the principle: entrust me with a job and I will find a technical solution. But without good admonition and supervision, this principle can prove to be extremely risky. While technique on the one hand allows students to realize their wildest dreams, on the other hand, technical megalomania and arrogance often lead to disasters. Students have a tendency to overestimate their abilities. It is extremely important to find a measure and adhere to it. Reason, in the sense of wisely leading one's life, and technical expertise, in the sense of a correct assessment of our possibilities, should form unity. Impatient youth cannot find that unity. Students lack the wisdom to use technology in a measured way. Students need to be given good advice on how to enter and exit the digital maze.

Bringing up students in the digital age presents some new challenges such as organizing time and relationships with other people. Students grow up not only consuming digital content but also creating and sharing it. Teachers witness daily that their students are up to date with new technologies and platforms. Most teachers are convinced that their students are fluent in the digital language. However, it is dangerous to think so. They may master applications and online platforms quickly, but they still need the guidance of a good, quality and modern teacher.

The students have incredible opportunities. Collaborating, creating and sharing has never been easier. Teachers and students must discover a way to properly take full advantage of interactive whiteboards, smartphones, laptops and other applications, as well as social networks. They must master the digital alphabet in an adequate way. With each tweet, post, content sharing, students and teachers build an image of themselves. It is a virtual walk on a wire. It happens that sometimes the wrong step happens. Correcting them is often a difficult and frustrating experience. Students need the help of a teacher. Teachers should help students develop all the skills they need to become digitally aware. If they do not master these skills, they will have big problems in the present and future world. The basic issues addressed in this paper are related to life, work and creativity, a crossroads at which the modern student and teacher stand. All of them were set with a single goal: to illuminate the digital profile of teachers and students of the Technical School Ivan Saric in Subotica as well as possible.

During the first semester of the 2019/2020 school year I conducted a research at the Technical School Ivan Saric. The research involved students who attend electrical, traffic and mechanical engineering courses and their teachers. 
The research was conducted in the form of workshops in which interviews were conducted with teachers and students. Teachers and students had the opportunity to express their views on how the digital age is changing their roles, opportunities and lives.

\section{VISIONS AND OPPORTUNITIES OF THE YOUNG GENERATION}

Through the young generation, the society conducts a dialogue with history. One side of that dialogue is turned to a critical re-examination of the past and the present, and the other, much more important, means turning society towards its own future. Hence, we call the young generation the generation of the future. Members of the modern young generation live in a society that provides them with numerous opportunities for creative expression and affirmation. However, reality and everyday practice show many resistances and obstacles along the way. Young generations are facing a struggle for affirmation in the whirlpool of modern society, which is increasingly characterized by dehumanization, alienated life and the gap between highly developed industrialized labor, on the one hand, and extreme backwardness and misery, on the other.

In any society shrouded in its transient or fresh mechanism of form, which deprives young people of the right to ask questions about their meaning, to express their values and understandings, which does not allow young people to actually participate in decision-making concerning their destiny, we are facing an explosion of dissatisfaction among young people who feel the absurdity of the system and their own alienation. The young generation has a universal tendency to adequately express and confirm themselves creatively. If they are denied that right, there is a revolt and protest (Järvenoja, Järvelä, 2009). The constant striving for freedom and revolutionaryism could be taken as common characteristics of the youth as a social group. It is characteristic of young people to change the conditions of empirical existence and strive for the new and undiscovered. Everyone to whom the future belongs, who progresses, grows and develops, must hope and imagine, dream and plan.

Youth as a heterogeneous social group represents a range of personalities from different classes, strata, races, different cultural, political and religious groups, but basically has two common features (Lareau, 2003): a) developed critical thinking, and b) great mutual mobility. These characteristics characterize the young generation regardless of geographic meridians or the social system they belong to. The world of automata and cybernetics has caused a real revolution. The scientific- 
technological revolution has caused the metamorphosis of the entire human life, and the young generation is the firstborn of this mutation (Keen, 2017). Hence, the conditions for its standard operation and behavior have changed. In the new conditions, with the penetration of modern technology, the responsible, stable and independent position of its professional bearers becomes a first-class factor. This factor has negative implications, too because there is a real danger of the concentration of social power within the technocratic framework (Turkle, 2012).

Today's young generation was born in the digital age. They are educated and brought up in it. Because of that, young people create a system of new values of cultural life, behavior and actions. Young people today often encounter resistance from generations that have formed their value under completely different conditions. Today's youth is facing older generations who are of the opinion that what has been achieved is important and that the achieved positions should be strengthened. A young person should be a fighter for the affirmation of knowledge, for the distribution based on the results of work, for new modern technology and modern methods of production, for solidarity among people, for solidarity in business relations. Such a person should be cooperative and communicative, but also consistent, i.e. that their words do not deviate from their deeds.

At the wider social level, the youth should be directed to the creation of new values and a new way of adhering to social rules, which are mostly affirmed independently of the wishes and will of the individual because they arise from the totality of social relations. The social structure of society is constantly changing. It is important that these changes take place in favor of the educated, scientific, creative, professional, cultural and artistic part of society. It is important to train the current young generations to be journalists and factors in that transformation of society. Young people will certainly have difficulties, misunderstandings, opposition and various other problems in that role, but a healthy, determined and cheerful spirit will surely overcome those obstacles.

The crossroads facing the younger generations are not marked by the same signposts. The degree of young people's awareness of their own values and role in society are the basic preconditions for their affirmation. The self - awareness of the youth group does not have to completely coincide only with the achieved level of cultural, socio - economic and political progress, but should go even further. 


\section{REALITY, BASIC VALUES AND ASPIRATIONS OF THE MODERN STUDENT}

Today's students are pushing cultural and neurological boundaries. Sometimes it is not entirely clear to them whether they are in the virtual or the real world, these are the generations that are less and less distinguishing between biological beings and machines. Robotics, nanotechnology and the internet are most deeply ingrained in their lives. Everything that students learn in school, all the values that their parents pass on to them outside school, all that is dispelled by the information and attitudes that technology sows (Hall, 2018).

Press the button and something will happen. The consequence of the above is that students do not have patience, that they are constantly looking for a change, they are hyperactive and often over-irritated. They expect to be entertained and visually stimulated and lose the ability to dedicate themselves and think (Steinkuehler, Duncan, 2008). For example, children used to make various things from Lego bricks. These toys actively occupied the mind and developed imagination and the ability to solve problems. An interesting question is whether any of this also applies to games in the virtual world. Probably, these games can also be useful, they probably have a positive effect on spatial intelligence and problem-solving skills, but they are artificial and cannot have the value of games created exclusively in children's imagination (Bers, 2012).

It is important to encourage students' curiosity, imagination and original thinking, because that is exactly what innovative companies are looking for. The modern age is very complex and extremely unpredictable. Changes happen from hour to hour, so very often we are faced with things that need to be radically rethought. The individual needs to adapt to unexpected situations and unfamiliar environments (Palvia et al., 2018). If, as children, we have participated in unstructured, arbitrary activities, we will develop better adjustment mechanisms. We will be more willing to look at situations openly and find new solutions to problems. It is important that the student is able to strike a balance between structure and chaos, experiment and routine, strategy and improvisation, in order to develop all his/her potentials (Baram-Tsabari, Yarden, 2005).

If students are restless and deconcentrated, we need to slow down, not speed up. The purpose of education should be to cultivate a sense of wonder and natural curiosity, as well as to develop a humane mind. The meaning of the teacher is not in what they think, but how they have changed the way the student thinks. We should therefore slow down education and be less burdened with swallowing information, we need less facts and more meaning (Brophy, 2015). 
Children should be children. They need to dream, unencumbered by time and practical goals. If we don't work on it, we will create a generation that will be able to offer quick answers but will have no idea how to ask a deep and meaningful question. Constant curiosity, combined with perseverance and free time, are the foundation of imagination and originality. Creative thinking is increasingly perceived as elitist, and we are witnessing mass stupidity. The world is accelerating more and more, it will become more and more technological, virtual and restrictive. What the students, and the rest of us, need is a counterweight. We need more freedom and experimentation. We need to wander more. We need more blank papers and pencils. We need to focus on what makes us unique as human beings (Keen, 2017).

Many years of teaching practice have shown me that: a) students like multitaxing, comparative work and personalized experience, read texts in a nonlinear way and prefer pictures to words; b) students often use digital devices to avoid conflicts and obligations; c) the restart generation believes that if something goes wrong, it is enough to just press the restart button and start again; d) the digital generation requires instant response and frequent praise and rewards, their brains are hyper-awake for multiple flows of information, although their attention and understanding may be narrowed; e) they have no need for direct human relations, which creates a generation that would rather cooperate with machines than with people; f) what they need to know, they search on Google; g) their minds are lively, but they often do not understand the wider context or culture.

It would be normal for global social values to be based on an adequate system of ideological, moral, cultural and other values. However, today we find ourselves in a kind of moral unrest. Old traditional values and moral norms have been dismantled, and new ones to replace them have not yet been created. Students are a group that absorbs and reflects all these changes in a fluid way. The whole learning process should bring into the world of ideas and utopian notions about the society of the future.

During the 2019/2020 school year, I conducted a survey among students of the Technical School Ivan Saric in Subotica. The research involved students who attend electrical, traffic and mechanical engineering courses. The research was conducted in the form of interviews and workshops. I wanted to see what the dominant interests and values of modern students are: sexual (35\%), sports adventurous ( $25 \%)$, technical (20\%), aesthetical - fun (10\%), religious - magical (5\%), political and economic (5\%).

The research showed that sexual interests are the most important for the students of the Technical School Ivan Saric. The sexual sphere expresses a new 
spirit of the times. The sexual sphere is just another expression of the consumer mentality and individualized psychology of our society, and therefore of the students in it. It is quite certain that the flood of mass media, various kitsch and cheap pornography, brought a hedonistic approach to the consciousness of young people. As a consequence of such a climate, an alienated, self-satisfied or extremely depressed person necessarily appears (Pierce, 2015).

Moreover, we can notice that sport is an area of great interest today. In the earlier period, the practice of mass sports was developed, amateur competitions based primarily on enthusiasm, and not on the pursuit of great international results. The lack of elementary props was compensated by the great enthusiasm and competitive spirit of the young people. Sport was primarily a pastime for the students, but also a factor of strengthening and cohesive connection. Today, sport is no longer mass entertainment. Sport has become a means of earning, and in many cases the possibility of easy and quick enrichment. A huge number of students can now consume sports pleasures only passively: to participate in matches through games, to watch and listen to various sports predictions, to read on the Internet about the earnings and comfortable life of athletes.

The means of mass communication overnight make stars out of individual athletes by sowing in young people false notions about the easy life, splendor and greatness of these people. The conducted research leads to a new aspect of the phenomenon: the values of the student population are shifting towards the values of the consumer society. In the digital age, consumer psychology has had a devastating effect on traditional values, which have long been dogmatized in the minds of young people.

Since we take students' awareness of their own possibilities and values as an important factor in their action, the question remains how developed this awareness of its value and role in the digital world really is. Creating student selfawareness should be a well thought out and organized task for every teacher. Students must be acquainted with the flows of social development and ideological movements in order to be able to apply the acquired experience and knowledge in practice. Students are a social group in the gap. How much they will be able to get out of that gap depends on their strength and awareness of their own ability to change something (Järvenoja, Järvelä, 2009). 


\section{A MODERN TEACHER BETWEEN FEARS AND POSSIBILITIES}

The school is essentially authoritarian in relation to the students. It is ruled by the relations of superiority and subordination, because students are only the one who learn and teachers are the one who teache them, without stating that they work alone and think about the set problems. The school has a lot of historically outdated heritage, stereotyped and rigid didactic practices, and above all authoritarian rules, which are incompatible with the healthy spirit of interpersonal relations. Can't teachers often learn a lot from students, who with their questions, curiosity, and even their ignorance, encourage them to think about whether their teaching and approach are good or not (Fredricks et al., 2004).

The teacher's leading role is reflected primarily in establishing proper relationships with students. In the old days, the relationship between teacher and student was quite formal, based on the blind subordination of students to the teacher. Only some teachers of that time realized that their basic task was to educate people who think independently. Most of them established a relationship with students who corresponded to the dogmatic character of teaching. The teacher explained - the students listened, the teacher ordered - the students carried out orders, the teacher asked - the students answered. Students were punished for not carrying out orders. Teachers are the ideological leaders of the young generation. They arm students with knowledge, present and explain teaching materials, guide their intelligent and practical work. The goal of teacher leadership is to raise students' awareness and awaken the aspiration in them (students) to acquire knowledge from various sources and to learn to work independently (Sanacore, 2008). Teachers encourage students to study carefully and at the same time make adequate demands on them. In this way, teachers achieve that students find their leader in them, that they treat them with respect and trust, that they work freely and actively.

Teachers should successfully assess themselves and their beliefs when it comes to technology. A digitally literate teacher is someone who approaches technology not with fear but with confidence; someone who is willing to progress and learn; someone aware of the risks that technology carries but who controls all the tools to deal with it (Alimisis, 2012). A modern teacher should become a mentor to the younger generations in learning the digital alphabet. A modern teacher must enable students to make good decisions and prepare them well for their online and offline future. The teacher's personal beliefs when it comes to mass culture, technology and media can influence the student's assumptions about what exactly 
quality is. Today, almost everything can be labeled as educational, including applications that do students homework and solve problems. Many teachers are generally confused when it comes to assessing what type of technology is positive for their students (Ertmer, 2005).

According to a research I conducted at the Technical School Ivan Saric during the 2019/2020 school year, in which 105 teachers participated, it showed that we have three main approaches to technology: 1) teachers who adhere to a restrictive approach to technology and who have less opinions; 2) teachers who talk to students about how to responsibly access technology, the Internet or a specific site; show and recommend to students books, articles, or programs to help them learn more about technology; 3) teachers who neither limit nor mentor and students are left to fend for themselves.

The students who participated in the research pointed out that they love technology when they can use it to create, learn, share and connect in new ways. Students are often annoyed by online learning when it takes longer to work on a task or when it causes teachers to pay less attention to them individually. The following is the answer given by a student who participated in the research: Teachers think they know what we are doing but they don't really know. In fact, they no longer teach the material. The lecture is now reduced to PP presentations, video content from Youtube or some link from the Internet. I have a growing distraction problem every day. I need more time to remember something and focus. I don't like spending so much time in front of a screen.

The research I conducted among the teachers of the Technical School Ivan Saric shows that teachers care the most: that their students are addicted to games and social networks; to have no social skills; that they are unable to concentrate on anything; that they will become cyber-bullies; to post an inadequate image or content; that students become more and more alienated and grow up in an unhealthy environment.

The teacher should lead the students to positively use technology and teach them to draw boundaries when necessary. Digitally aware use of technology will lead students to achieve their goals and be well prepared for life's challenges in the future. Teachers need to start from the assumption that students want to do the right thing just don't always know how. This simple assumption will open the door for them to talk to students about their world - from social interactions and games to the challenges and frustrations they experience (Palvia et al., 2018).

Open communication is key to a quality relationship with students. Teachers must always start from positive assumptions. The intentions of the students are generally simple. They mostly try to connect with friends, find like-minded people 
and share their feelings, ideas and events with someone (Brophy, 2015). Technology adds new, complex levels to these natural needs. If you teach students to participate in the digital world in a positive and active way, the effects of that will be reflected on their interactions at home, in society and beyond (Palloff, Pratt, 2013).

According to the students of the Technical School Ivan Saric who participated in the research, a teacher who is in favor of technology should: think about the quality application and use of technology; be an example of civilization in his correspondence with students, parents and colleagues; draw clearly defined boundaries and adhere to them, as they expects from their students; teach students digital ethics; teach students to respect other people's privacy in the digital world; with the help of technology, lead to positive changes in upbringing and education.

Students learn patterns of behavior and values by looking at their teachers. Do you send messages while your students are talking to you? Do you check emails while they are nearby? Do you answer your cell phone during a lecture? In this way, we do not give students an example of what good communication is and how to use computers, mobile phones and other digital media in the right way. One of the basic tasks of teachers is to teach modern generations patience and focus. The speed of communication is one of the advantages of today's world, but on the other hand, it increases the feeling that everything must be done immediately. Students have the feeling that they should do everything quickly and superficially, and that is why they often make mistakes. Teachers need to reassure students that it is okay to stop, think, and slowly gain an insight into what they need to do. Spotting a mistake, correcting it and focusing on further work is the best way to get over every problem.

The teacher's leading role is also manifested in the fact that it arouses the student's desire to learn, creates interest in the subject being taught and thus stimulates the student to careful and fruitful knowledge. An experienced teacher is able to predict the course of learning, to guide students on the best path and to prepare them to overcome the difficulties that arise before them (Brophy, 2015). According to the teachers of the Technical School Ivan Saric who participated in the research, we can stimulate students in the modern teaching process in the following ways: 1 . By focusing on free play rather than on organized and structured activities in order to avoid neglecting the imagination; 2. emphasizing both creative and rational content in order to achieve the original and logical opinion that companies are looking for today; 3 . find a way to help working parents spend more time with their children; 4 . encourage parents to limit the time students spend in the virtual world; 5. not allow information and attitudes from electronic devices divorce lessons from those values that students receive from parents and teachers. 


\section{CONCLUSION}

The modern age is very complex and extremely unpredictable. Changes happen from hour to hour, so very often we are faced with things that need to be radically rethought. The teacher is forced to adapt to unexpected situations and unfamiliar environments. The basic role of the teacher in modern education is to help students strike a balance between structure and chaos, experiment and routine, strategy and improvisation, in order to develop all their potentials.

The conducted research showed that the introduction of modern technology in the teaching process and its increasing application bring significant changes. Among them, one of the most significant is the changed role of teachers and students in the teaching process. The main goal and final outcome in the transformation of teaching is not the introduction of new teaching technology, expressed by the number of computers in schools, the number of electronic classrooms, the introduction of the Internet and the like, but their changed didactic function. In fact, it is about how much their application creates conditions for the transformation of teaching into such a spiritual workshop in which, under the supervision of teachers, knowledge, habits and skills are not acquired by mechanical learning, but achieved by patient search effort.

By developing independence and creativity, modern teaching technology contributes to the student's ability to self-organize their activities. More and more often, students have the opportunity to collect the necessary data themselves, to critically check the collected facts in accordance with the set hypotheses, to come to a number of scientific truths through their own work, which frees the teacher from the obligation to make only his/her own authoritative judgment.

Technology is a tool for learning and many other things. If used properly, technology awakens the creativity we all possess by nature. Teachers need to understand that by solving problems together with students, they develop their creativity and at the same time build trust. A teacher can learn from a student as much as a student can learn from a teacher. Students like to be guided by someone. They want and need advice in the digital age. The digital alphabet implies a set of skills that can be learned. Students are prone to technology, but teachers are wiser and more experienced. 


\section{REFERENCES}

1. Alimisis, D. (2012). Robotics in education \& education in robotics: Shifting focus from technology to pedagogy. In Proceedings of the 3rd International Conference on Robotics in Education, (pp. 7-14).

2. Baram-Tsabari, A., Yarden, A. (2005). Characterizing children's spontaneous interests in science and technology. International Journal of Science Education, 27 (7): 803-826.

3. Bers, U. M. (2012). Desiging Digital Experiences for Positive Youth Development: From Playpen to Playground. New York: Oxford University Press.

4. Brophy, J. (2015). Motivating Students to Learn. Beograd: Clio.

5. Ertmer, P. (2005). Teacher pedagogical beliefs: The final frontier in our quest for technology integration? Educational Technology Research \& Development, 53 (4): 25-39. https://doi. org/10.1007/BF02504683 (1/3/2021)

6. Fredricks, J. A., Blumenfeld, P. C., Paris, A. H. (2004). School engagement: Potential of the concept, state of the evidence. Review of Educational Research, 74 (1): 59-109.

7. Hall, T. (2018). Education, Narrative Technologies and Digital Learning. Palgrave Macimillan UK.

8. Järvenoja, H., Järvelä, S. (2009). Emotion control in collaborative learning situations: Do students regulate emotions evoked by social challenges? The British Journal of Educational Psychology, 79 (3): 463-481. https://doi.org/10.1348/000709909X402811 (1/3/2021)

9. Keen, A. (2017). The Internet is not the answer. New York: Atlantic Monthly Press.

10. Lareau, A. (2003). Unequal Childhoods: Class, Race, and Family Life. Berkeley: University of California Press.

11. Pierce, C. (2015). Sexploitation: Helping Kids Develop Healthy Sexuality in a Porn-Drive Word. Brookline, MA: Bibliomotion.

12. Palloff, R. M., Pratt, K. (2013). Lessons from the Virtual Classroom: The Realities of Online Teaching. San Francisco: Josssey - Bass.

13. Palvia, S., Aeron, P., Gupta, P., Mahapatra, D., Parida, R., Rosner, R., Sindhi, S. (2018). Online education: Worldwide status, challenges, trends, and implications. Journal of Global Information Technology Management, 21 (4): 233-241 https://doi.org/10.1080/1097198X.2018.1542262 $(1 / 3 / 2021)$

14. Sanacore, J. (2008). Turning reluctant learners into inspired learners. The Clearing House: A Journal of Educational Strategies, Issues, and Ideas, 82 (1): 40-44.

15. Steinkuehler, D., Duncan, S. (2008). Scientific habits of mind in virtual worlds. Journal of Science Education and Technology, 17 (6): 530-543. https://doi.org/10.1007/s10956-008-9120-8 $(1 / 3 / 2021)$

16. Turkle, S. (2012). Why We Expect More from Technology and Less from Each Other. New York: Basic Books.

17. Wright, M. (1966). Knowledge and Power. Belgrade: Vuk Karadžić. 


\section{DIGITALNA ABECEDA - IZAZOV SUVREMENOGA UČENIKA I UČITELJA}

\section{SAŽETAK}

Plodovi digitalnoga doba postali su ključni dio svakodnevnoga života stotina milijuna kućanstava, ureda $i$ škola širom svijeta. Naša se komunikacija odvija puno više tekstualnim porukama i e-poštom nego licem u lice, a prvo mjesto na kojem tražimo informacije jest Google. Posljedice ove tehnološke sveprisutnosti i elektroničke poplave značajne su promjene u stavovima kao i u ponašanju učenika i učitelja, a cilj je ovoga rada ispitati te pomake. Kako digitalno doba mijenja mogućnosti, vrijednosti i živote učenika i učitelja - što se dogada sada, što nas očekuje u budućnosti? Mogu li digitalna postignuća doista promijeniti način razmišljanja ili ponašanja učenika $i$ učitelja? Uče li i učenici i učitelji novu abecedu - digitalnu abecedu?

Ključne riječi: digitalno doba, budućnost, student, učitelj, mladi. 